\title{
ANTÔNIO FLÁVIO PIERUCCI: SOCIÓLOGO MATERIALISTA DA RELIGIÃO
}

\section{Ricardo Mariano}

Quanto mais velho vou ficando e mais maduro na profissão, mais me convenço de que nunca se é excessivamente materialista quando o que se pretende

honestamente fazer é, com todas as letras e todas as exigências epistemológicas e implicaçōes deontológicas, sociologia da religião. A ciência cientifica como vocação, afinal. Antônio Flávio Pierucci, $O$ desencantamento do mundo,

p. 84.

A sociologia brasileira, em especial a sociologia da religião, perdeu, em 8 de junho de 2012, um de seus principais expoentes nas duas últimas décadas: Antônio Flávio de Oliveira Pierucci. "Encantou-se”, poetizou carinhosa e sagazmente um jornalista.

Este artigo, acima de tudo, visa homenageá-lo e ao legado sociológico que nos deixou. Para tanto, discorre sobre sua exitosa carreira acadêmica, narra algumas de suas escolhas intelectuais, seus embates

Artigo recebido em 15/01/2013

Aprovado em 25/01/2013 teóricos e, sem qualquer pretensão de mapeá-la a fundo e por completo, apresenta parte de sua obra, enfocando, de forma sucinta e lacunar, sua sociologia da religião de corte weberiano.

Em primeiro lugar, devo dizer que Flávio Pierucci foi meu mestre e meu amigo querido por duas décadas e meia. Convivência que me permite assinalar - para referir-me à sua pessoa - que ele era espirituoso, carismático, jovial, piadista, irreverente, irônico, autêntico, temperamental, afetuoso, generoso, cerebral e emotivo, apolíneo e dionisíaco. Quem o conheceu de perto sabe que Flávio (como os amigos o chamavam) era, como se diz popularmente hoje, "uma figura". Especial. Marcante.

No campo profissional, era um professor motivado e estimulante, gestor dedicado, debatedor contundente e polemista instigante, pesquisador antenado, escritor habilidoso, revisor cuidadoso. Era um defensor de teses fortes e de posiçôes e valores democráticos, republicanos e seculares. Estudioso, tinha paixão pela leitura metódica (de feitio 
ascético, pode-se dizer) e pela reflexão teórica. Era afeiçoado à escrita escorreita, refinada, erudita, à qual se dedicava com enorme prazer, inclusive, desde jovem, à poesia, que não se dispôs a publicar. Como pesquisador, procurava primar, acima de tudo, pela lógica, pela coerência e pela precisão das ideias, dos argumentos, dos conceitos e da amarração teórica.

Sua principal característica intelectual, a meu ver, consistia em tentar conduzir a reflexão conceitual e teórica a suas últimas consequências lógicas ou racionais. Não à toa, assim se pronunciou em $O$ desencantamento do mundo: "Luta por clareza. Este meu trabalho sobre Max Weber tem a ver com essa luta, que era dele mas que também é minha, e eu sinceramente acho, tal como ele achava, que ela deve ser de todos os que se ocupam profissionalmente de uma ciência. De confusa e embaralhada, basta a vida real [...]" (Pierucci, 2003, p. 37). Luta intelectual por clareza conceitual, teórica e na escrita que se bem expressa em sua obra, que tanto sacudiu a sociologia da religião brasileira nas duas últimas décadas e que, por seus méritos e insights, continuará sendo revisitada.

\section{A sociologia como vocação}

Em seu Memorial para o concurso de professor titular de sociologia da USP, Flávio afirmou (como se predestinado fosse para a vocação e a carreira sociológicas) que foi "treinado desde a infância a encarar os estudos como um destino" por influência do avô e do pai (Pierucci, 2006a, p. 77). Nascido em 28 de agosto de 1944 em Altinópolis, interior de São Paulo, desde criança adorava ler e lia muito, a ponto de tomar bronca por fazê-lo até no escuro. Aos 11 anos, entrou para o seminário menor da diocese de Ribeirão Preto. Em seguida, graduou-se em filosofia (1962-1964), no Seminário Central da Arquidiocese de São Paulo, e em teologia (19651968) na PUC-SP. Entre 1968 e 1970, cursou doutorado em teologia dogmática na Pontifícia Universidade Gregoriana, Roma, o qual abandonou três meses antes de findar o prazo para a defesa da tese, após romper com a igreja e desistir da carreira eclesiástica como docente e periodista.
Aos 26 anos, desempregado, sem o sustento provido pela igreja e morando numa república com mais cinco estudantes no centro velho de São Paulo, durante uma festa de aniversário - por acaso - foi informado por um grupo de jovens que o Cebrap (Centro Brasileiro de Análise e Planejamento), o qual desconhecia, iniciaria uma pesquisa sobre mudanças no cristianismo no país. Seguiu a dica. $\mathrm{Na}$ antiga sede no bairro de Higienópolis, foi entrevistado por Candido Procopio Ferreira de Camargo, então presidente do Cebrap e responsável pelo setor de religião, que o contratou como auxiliar de pesquisa para investigar as "Mudanças nas funçōes sociais do cristianismo no Brasil". Assim, em março de 1971, dotado de uma pequena bolsa da Fundação Ford, teve início sua experiência com a pesquisa acadêmica, estopim de sua descoberta da sociologia como vocação. Vocação profissional estimulada por Candido Procopio, pelo convívio com as primeiras gerações de pesquisadores do Cebrap e por suas próprias disposiçôes intelectuais. O Cebrap, sem dúvida, foi a instituição fundamental em sua formação sociológica e em seus passos iniciais na nova carreira, sendo complementado e substituído posteriormente pela FFLCH-USP.

Seus primeiros anos como auxiliar e aprendiz de pesquisador foram dedicados, mais que tudo, ao estudo da sociologia, em especial da sociologia da religião e da sociologia weberiana, ambas sob a batuta de Candido Procopio. No Cebrap, logo viu reconhecida sua elevada capacidade para a escrita, para a pesquisa e como revisor de texto, habilidades comprovadas também ao tornar-se redator e consultor, entre 1972 e 1976, de verbetes e fascículos sobre diferentes religiōes para a editora Abril Cultural. Reconhecimento que o levou a assumir a revisão dos textos publicados na revista Estudos Cebrap e na série Cadernos Cebrap. Entre 1974 e 1975, lecionou sociologia na Faculdade de Filosofia Nossa Senhora Medianeira.

Foi sob a orientação de Candido Procopio - a quem definiu como "meu Mestre, meu grande treinador, quase um guru não fora seu afiado senso de autocrítica" (Pierucci, 2006a, p. 73) - que Flávio defendeu, em junho de 1977 na PUC-SP, a dissertação Igreja Católica e reprodução humana no Brasil, publicada pela Brasiliense no ano seguinte com o tí- 
tulo Igreja: contradiçôes e acomodação. A ideologia do clero católico sobre a reprodução humana. Em 1978, passou em concurso público para o Departamento de Sociologia da Faculdade de Ciências Sociais da PUC-SP, onde permaneceu até 1985. Neste ano, sob a orientação de Reginaldo Prandi - "a amizade maior de todas em minha vida” (Idem, p. 74) -, defendeu na USP a tese de doutorado Democracia, igreja e voto: o envolvimento eleitoral do clero paroquial de São Paulo nas eleições de 1982. Em 1986, ingressou por concurso público no Departamento de Ciências Sociais da USP como professor visitante de sociologia com uma bolsa de recém-doutor do CNPq de dois anos, sendo contratado como professor assistente em janeiro de 1988, quando deixou o Cebrap após 17 anos em seu staff.

Logo em seguida, ocupou prestigiosas posiçóes de gestão acadêmica. Entre 1990 e 1992, coordenou o curso de Pós-Graduação em Sociologia da USP, experiência gestora que o projetou para o posto de secretário-executivo da Anpocs, o qual exerceu por dois mandatos (1992-1996). Em 1997, coordenou o Comitê Assessor de Ciências Sociais do CNPq, entre 1998 e 2001, integrou o comitê de avaliação do Pronex do CNPq e, de 1998 a 2000, a diretoria da Associación de Cientistas Sociais de la Religión del Mercosur (ACSRM). Em meio a toda essa tarefa administrativa, em junho de 2001, defendeu, na FFLCH-USP, a tese de livre-docência $O$ desencantamento do mundo: todos os passos do conceito em Max Weber, publicada em 2003 pela Editora 34. De 2001 a 2003, exerceu mandato de secretário-geral da SBPC (Sociedade Brasileira para o Progresso da Ciência) e, de 2001 a 2004, a função de editor da Novos Estudos Cebrap. Em 2006, tornou-se professor titular de sociologia da USP, alcançando o auge da carreira universitária. Quando faleceu, chefiava o Departamento de Sociologia da USP.

No Lattes, Flávio se apresentava como "especialista em sociologia da religião e teoria sociológica alemâ". ${ }^{1} \mathrm{Na}$ pele de um especialista em sociologia da religião, sempre fazia questão de identificar-se publicamente como sociólogo não religioso da religião ou desprovido de "ouvido musicalmente religioso", cioso que era de seu approach acadêmico, de sua visada científica num meio, a seu ver, nem tanto. Já por sociologia alemã leia-se, principalmente, Max Weber, que qualificava de "monstro sagrado da sociologia" e por cuja obra nutria enorme admiração. Tanto que se dizia weberiano e "weberólogo". E se comprazia da esmerada edição crítica d'A ética protestante e o "espirito" do capitalismo - publicada pela Companhia das Letras em 2004 em comemoração ao centenário de sua primeira edição -, projeto editorial para o qual contribuiu desde sua formulação original e com a escrita da apresentação, da tábua de correspondência vocabular e do glossário. Em reconhecimento dos editores à sua erudição e extrema dedicação, a capa da obra magna de Weber estampou "Edição Antônio Flávio Pierucci". Nos últimos anos, vinha trabalhando na revisão técnica do restante dos Ensaios reunidos de Sociologia da Religiäo.

\section{Especialização e carreira em sociologia da religiáo}

Entre a segunda metade dos anos de 1970 e a primeira metade dos de 1980, Flávio embrenhou-se ainda mais na sociologia da religião para a obtenção dos títulos de mestre e doutor, pesquisando a relação da Igreja Católica com a reprodução humana e o aborto e o engajamento do clero católico nas eleições estaduais de 1982, respectivamente. Primeiro, por meio de análise documental e pesquisa empírica, procurou mostrar que a filial da Santa Sé não constituía uma barreira monolítica ao planejamento familiar, dada a desunião do clero sobre a matéria, algo que transparecia nos discursos de suas diferentes instâncias de autoridade. A despeito do consenso da oposição oficial do episcopado ao controle de natalidade e às proposições neomalthusianas do Estado como solução para o subdesenvolvimento e a miséria, vigoravam a permissividade e o casuísmo do baixo clero, diante das demandas e pressōes dos fiéis, no trato da micromoralidade familiar relativa ao uso de métodos anticonceptivos (Pierucci, 1978).

Para o doutorado, efetuou ampla pesquisa qualitativa e, sobretudo, quantitativa com padres de paróquia da Arquidiocese de São Paulo, visando compreender o envolvimento partidário e eleitoral do clero paulista nas eleições de 1982 e suas opiniốes e atitudes sobre os partidos recém-criados 
no contexto da distensão política e do retorno do pluripartidarismo (Pierucci, 1985). A tese não foi publicada, mas originou, em 1986, "O povo visto do altar: democracia ou demofilia?”, artigo luminar que evidenciou várias clivagens ideológicas no clero católico por meio da pesquisa de suas diferentes percepções teológicas e sociopolíticas do conceito de povo, associadas fortemente a distintas faixas etárias e preferências partidárias. Apesar de suas divergências internas, o clero, em uníssono, sustentava radical convicção da existência de uma indissolúvel "aliança mística Igreja-Nação", ou entre Igreja e povo brasileiro, segundo a qual estaríamos todos "condenados ao catolicismo" (Pierucci, 1986, p. 80). Enquanto isso, já avançava célere o desmonte do monopólio católico...

\section{Direita e diferença}

Em 1986, iniciou a investigação empírica da direita política e do voto conservador em São Paulo, sobretudo das bases janistas e malufistas, que resultou, no ano seguinte, na publicação de "As bases da nova direita: seus medos, seu dedo". Em seguida, investiu na pesquisa sociológica sobre a relação entre direita e diferença, temática que dominou boa parte de sua produção acadêmica até meados da década de 1990 e que chegou a cogitar desenvolver como tese de livre-docência. Em vez disso, decidiu reunir sete artigos, dois inéditos e cinco dos melhores que publicara sobre o tema entre 1987 e 1995, para compor Ciladas da diferença, lançado pela Editora 34 em 1999. Neste livro, procurou demonstrar as armadilhas teóricas que a nova esquerda dos movimentos sociais, dos movimentos de minorias sobretudo, enfrentava ao investir no léxico da diferença, ao valorizar e defender a diferença, ao tematizar o direito à diferença, vocabulário, valor, temática e estratégia política que, desde a Revolução Francesa, eram todos atavismos e arsenais ideológicos que a direita acionava vigorosamente para resistir e se opor aos Direitos Humanos e aos ideais republicanos de igualdade e fraternidade (Pierucci, 1999a). "Foram as pesquisas 'eleitorais' sobre a direita", revelou, "que acabaram me levando a mergulhar fundo nas águas dos discursos diferen- cialistas e ali encontrar, como faces da mesma moeda, o elogio da diferença e a recusa do igualitarismo" (Pierucci, 2006a, p. 58).

Concomitantemente com a pesquisa das bases populares de partidos e plataformas políticas da direita paulista e a diferença, Flávio passou a investigar, entre 1987 e 1988, a emergência de uma "direita cristã" no parlamento brasileiro, isto é, a bancada evangélica na Constituinte e, de 1989 a 1993, "A politização à direita do pentecostalismo no Brasil", pesquisas das quais participei como seu assistente enquanto cursava a graduação e o mestrado. Elas resultaram na publicação de dois artigos sobre o ativismo político pentecostal, destacando, então, sua ruptura com o apolitismo sectário, seus pendores moralistas, suas investidas fisiológicas, suas alianças e filiações político-partidárias esmagadoramente de direita, sua defesa contumaz da liberdade religiosa contra o "comunismo petista" e sua estratégica participação na primeira eleição presidencial pós-ditadura: "Representantes de Deus em Brasília: A bancada evangélica na Constituinte" (Pierucci, 1989) e "O envolvimento dos pentecostais na eleição de Collor” (Mariano e Pierucci, 1992).

\section{Secularização e desencantamento}

$\mathrm{Na}$ segunda metade da década de 1990, Flávio ensejou um debate acadêmico ao questionar a cientificidade da sociologia da religião feita por pesquisadores religiosos. Publicou dois alentados artigos intencionalmente polêmicos sobre o tema: "Interesses religiosos dos sociólogos da religião" (Pierucci, 1997a) e "Sociologia da religião: área impuramente acadêmica" (Pierucci, 1999b), ambos inspirados na conferência de Bourdieu (1990) "Sociólogos da crença e crenças de sociólogos”, na qual o formulador do conceito de campo religioso critica severamente os sociólogos religiosos da religião pela "cumplicidade" com a religião, pela "relação de má fé com a ciência”, pelo "jogo duplo" entre ciência e religião com vistas à "dupla vantagem". Para "evitar as desvantagens anticientíficas do jogo duplo", defendeu, seguindo à risca Bourdieu, que é preciso objetivar a pertença religiosa e "submetê-la a um esforço de objetivação reflexiva sem complacência" 
(Pierucci, 1999b, pp. 276-277). E, a fim de recuperar o prestígio acadêmico da sociologia da religião, criticou os interesses religiosos e a irrefletida sociologia religiosa dos que se empenhavam em valorizar a religiáo e exaltar o retorno do sagrado, a revanche de Deus. Em defesa do rigor científico, pontificou que "a sociologia da religião só é possível porque tem na crítica moderna da religião sua condição pós-tradicional de possibilidade enquanto ciência moderna, enquanto ciência científica" (Idem, p. 278).

Seu engajamento nessa polêmica esteve associado desde o início à disputa entre defensores e oponentes da teoria da secularização, debate teórico dos mais calientes na sociologia da religião que, qual rastilho de pólvora, se espraiou mundo afora também entre filósofos, historiadores, juristas e antropólogos. De forma corajosa, apaixonada e provocativa, ele entrou de sola nesse debate, mas na contracorrente, sabendo-se partidário e expoente de uma perspectiva teórica já minoritária, sob pressão e na defensiva. Nem por isso recuou ou economizou munição, sobretudo a conceitual e de extração weberiana. Não retrocedeu quando Peter Berger (2001), autor da versão sociológica mais popular da teoria da secularização, passou a falar em dessecularização e refutou bombasticamente sua tese pregressa que associava, de forma indissolúvel, modernização e secularização, paradigma teórico canônico na sociologia que perdurou mais de meio século até o início dos anos de 1990. Não renunciou à sua posição teórica quando pesquisadores e intelectuais sem fim, atordoados e mobilizados pelos atentados terroristas comandados por grupos islâmicos radicais às torres gêmeas e a outros tantos alvos ocidentais, passaram a alardear que estávamos a viver numa era pós-secular.

Sua estreia nesse debate se deu com a publicação de "Reencantamento e dessecularização: a propósito do auto-engano em sociologia da religião", ${ }^{2}$ em 1997, versando sobre a "secularização da sociedade" moderna, o "persistente declínio da religião", porque banida do centro que articula a coesão social, da posição axial que ocupava nas sociedades tradicionais e de seu "papel de matriz cultural totalizante" (Pierucci, 1997b, pp. 100-104). Criticou os argumentos teóricos dos adversários, aludiu a suas propensōes neoconservadoras, repeliu a suposta crise de paradigma no núcleo duro da teoria macrossocial da secularização, sublinhou o declínio da religião e dos poderes religiosos sobre a sociedade, as instituiçóes, a alta produção cultural, a universidade, a filosofia, a ciência, a música pop, as esferas do entretenimento e dos esportes, a cultura jovem, destacou a secularização do lazer e do tempo livre, incluindo a secularização do domingo, o outrora "dia do Senhor", a secularização do prazer sexual, da sexualidade, da procriação e da família, em suma, de áreas cruciais até da vida privada, justamente onde religiōes e religiosidades tendem a apresentar maior vitalidade na modernidade.

Ao contrário do que se pode pressupor a partir dessas afirmações, cabe frisar que Flávio pesquisou, constatou e evidenciou a proliferação de crenças, práticas, religiosidades e religióes mágicas no Brasil, bem como de terapias, literaturas, objetos e cursos esotéricos, New Age, espiritualistas, alternativos, holísticos. Em $A$ magia, livro lançado em 2001 e no qual compara, distingue e esmiúça os conceitos de magia e religião, asseverou: "nestes tempos que nos toca viver $[\ldots]$, parece que não para mais de crescer a oferta plural e multicultural de saídas mágicas para todo tipo de problema" (Pierucci, 2001, p. 42). Atestou também o crescimento de grupos religiosos dispostos a moralizar nossa vida, a fazer proselitismo diuturnamente, a expandir indefinidamente sua visibilidade midiática, seu marketing religioso e sua presença no espaço público. O fato é que, de um contexto que conjuga desregulação estatal da religião, liberdade religiosa, extensa religiosidade popular de cunho mágico e taumatúrgico e pluralismo religioso e cultural, ele não esperava outra coisa senão maior mobilização religiosa e sucesso dos grupos mais ativamente dedicados ao proselitismo, mas também maior trânsito religioso e destradicionalização religiosa, maior individuação e subjetivação da religião, mais inovaçôes, bricolagens e sincretismos religiosos, mais experimentações privatizantes, heterodoxas e reflexivas da religião, mais defecçóes religiosas, além de mais disputas, polêmicas e conflitos religiosos, culturais e políticos.

Manejando argumentação complexa e refinada, Flávio sustentou que a expansão dos novos movimentos religiosos e o processo de secularização não são fenômenos necessariamente incom- 
patíveis (Pierucci, 1997b). Isso porque, na esteira de Bryan Wilson, considerava que a própria secularização da sociedade explica, em boa medida, "a emergência de expressões religiosas não-tradicionais" e que o avanço do pluralismo religioso "não é apenas resultado, mas fator de secularização crescente" (Idem, pp. 112, 115). A seu ver, um contexto religioso pluralista e de crescimento da oferta de opções religiosas tende a desenraizar os indivíduos da tradição e a promover "a dessacralização da própria cultura como condição de possibilidade de trânsito religioso legítimo" e da "apostasia como conduta socialmente aceitável”, ao passo que "mobilizar religiosamente um indivíduo implica fazê-lo duvidar da santidade da tradição religiosa, lançando-o no pós-tradicional, abrindo-o para a apostasia" e para "tantas outras quebras de lealdade" (Idem, pp. 114-115).

Em 1998, voltou à carga com "Secularização segundo Max Weber: da contemporânea serventia de voltarmos a acessar um velho sentido", texto no qual recalibrou, delimitou e precisou rigorosamente seu instrumental conceitual. Para lidar com o problema da polissemia e dos múltiplos e arrevesados usos do conceito de secularização, circunscreveu-o à esfera institucional jurídico-política ou à formação do Estado nacional moderno. Ressaltando provocativamente que "saber do que se fala sempre ajuda", sábias palavras de Habermas (Pierucci, 1998, pp. $43,67)$, optou por examinar de forma minuciosa o conceito de secularização na sociologia do direito de Weber, pondo o foco analítico na secularização da normatividade jurídico-política. Enfatizou a interface da secularização com a racionalização e legitimação da dominação política, a autonomização desta em relação aos poderes hierocráticos, a formação do Estado secular como domínio da lei e a própria dessacralização da lei, processo racionalizante que tornou a legislação moderna discutível e revisável (Idem). A factibilidade histórica indubitável desse macroprocesso de secularização do Estado moderno (excetuadas as teocracias), a seu ver, permitia firmar sólida base para um consenso teórico provisório mínimo em torno de um núcleo fundamental do conceito de secularização e, com isso, escapar das intermináveis discussōes focadas na interpretação e mensuração de dados empíricos sobre a religiosidade privada e a expansão ou o declínio de grupos religiosos.

Em meio a calorosos embates sobre a cientificidade da produção dos sociólogos religiosos da religião e a teoria da secularização, Flávio cogitou fazer um "balanço crítico" da "sociologia da religião tal como era feita no Brasil" (Pierucci, 2006a, p. 33). Mas desistiu da empreitada por não querer se indispor mais ainda com colegas e nem adquirir a desconfortável imagem de palmatória do mundo (Idem). Animado com os resultados teóricos de seu sistemático estudo do conceito de secularização na sociologia weberiana, decidiu elaborar a tese de livre-docência sobre o conceito de desencantamento do mundo na obra de Weber, que virou seu único livro teórico sobre a produção do sociólogo de Heildelberg: Desencantamento do mundo: todos os passos do conceito em Max Weber.

Nesse verdadeiro trabalho de scholar, rastreou, contextualizou e examinou exaustivamente os dezessete usos que Weber fez do conceito de desencantamento do mundo (desmagificação), realçando "sua consistência lógica e sua fixação num par de sentidos ao longo das sucessivas utilizações" (Pierucci, 2003, p. 35), a saber: 1) desencantamento do mundo efetuado pela racionalização religiosa (com sua ética, suas noções de pecado, sua metafísica dualista, seus intelectuais), despojamento da magia como meio de salvação radicalizado pelo protestantismo ascético; 2) desencantamento do mundo deflagrado pela ciência, que transforma o mundo natural em mero mecanismo causal e destitui a vida de qualquer sentido ou valor intrínseco já que não tem como prová-lo cientificamente. Mostrou seu vínculo estreito com o conceito de racionalização e com o projeto teórico do alemão de compreender o desenvolvimento e a especificidade do "racionalismo de domínio de mundo" e da modernização ocidental. Destacou também "o ponto de vista sem-religiāo sobre a religião" de Max Weber e "sua perspectiva materialista e decididamente intramundana" sobre os interesses religiosos (Idem, p. 84), perspectiva intelectual e teórica que compartilhava plenamente. Tanto que, seguindo Weber e Bourdieu, defendia que "ninguém nasce religioso", mas se torna religioso "produzido por profissionais da religião, por especialistas em religião, pelos peri- 
tos do discurso místico, pelos experts da metafísica, pelos virtuoses de ouvido musicalmente religioso" (Idem, pp. 81-82).

\section{Destradicionalização religiosa}

Em "'Bye bye, Brasil': o declínio das religiōes tradicionais no Censo 2000", questionou a tão decantada diversidade religiosa brasileira, constatando que, ao excetuar católicos, evangélicos e sem religião, restavam apenas 3,5\% de brasileiros filiados às demais religiōes, menos de seis milhôes numa população de 170 milhões (Pierucci, 2004). Em face do persistente declínio numérico do catolicismo sucedido pela queda do luteranismo e da umbanda, realçou o acelerado ocaso do Brasil tradicional no campo das religiōes, advogando que tais filiações tradicionais decaíam à medida mesma que as pertenças religiosas, sociais e culturais se tornam opcionais nas sociedades pós-tradicionais (Idem). Mudança religiosa impulsionada igualmente, mas com efeito retardado, pela separação republicana entre igreja e Estado, marco jurídico-político fundante e fundamental que, reforçado posteriormente pelo processo de modernização socioeconômica e cultural, assegurou, a partir da segunda metade do século XX, o avanço da liberdade de culto e da liberdade individual de escolha religiosa, a consolidação do pluralismo religioso (embora esmagadoramente cristão), o recrudescimento da concorrência inter-religiosa e, por tabela, a emergência de novos conflitos de grupos religiosos entre si e com agentes seculares.

Aprofundou e reformulou a reflexão sobre a destradicionalização religiosa a partir de outro insight teórico no artigo "Religião como solvente uma aula" (Pierucci, 2006b). Para tanto, retomou, primeiramente, as definições de Candido Procopio, em Católicos, protestantes e espíritas, de religiōes étnicas (minoritárias e voltadas à preservação de patrimônio étnico-cultural) e religióes universais (abertas a todos, sem exceção). Recategorizou esta última como "religião de conversão", pontuando que ao se converter o fiel passa de um status religioso adscrito (de origem familiar) para um status adquirido por escolha e frisando que as religiões étnicas no Brasil, invariavelmente, se tornaram uni- versais ao longo da segunda metade do século XX. Acionou, então, o conceito weberiano de religião congregacional de salvação individual, ponto nodal do texto, para argumentar que as religióes congregacionais e soteriológicas, proselitistas por natureza, formam comunidades de fiéis extraindo indivíduos de suas coletividades, desenraizando-os de suas linhagens, procedências e relações sociais herdadas, tornando-os mais individualizados, ao engajá-los individualmente em uma nova comunidade a partir de motivações, crenças, valores, moralidades e da tessitura de laços puramente religiosos (Idem, pp. 120-122). A lógica individualizante da adesão religiosa inerente ao conceito de religião congregacional de salvação, a seu ver, antecipa a "configuração religio-cultural" da dinâmica da modernidade religiosa, em mutação constante (Idem, p. 122).

Cabe observar que a modernidade religiosa se caracteriza, entre outras coisas, por uma vigorosa individualização e subjetivação das crenças, práticas e experiências, radicalizada e massificada pelo movimento da contracultura, responsável por fragilizar as pertenças e instituiçõos religiosas tradicionais (Hervieu-Léger, 2008). Haja vista que a validação, a autenticação e o julgamento das crenças, práticas, convicções e éticas religiosas tendem a ser efetuados de forma cada vez mais autônoma pelos indivíduos em busca do cultivo de si e de autoexpressão a partir e em função, sobretudo, de insights, experiências e sentimentos pessoais e em detrimento de autoridades externas, exigências institucionais e prescrições heterônomas de ortodoxias e de moralidades rígidas e extemporâneas (Taylor, 2010, pp. 555-592).

Em dois de seus últimos artigos, Flávio propôs justamente que a sociologia da religião deve ser uma sociologia da modernidade religiosa, devendo enfocar a religião como fator de mudança cultural e considerar a própria mudança religiosa importante forma de mutação cultural (Pierucci, 2008; Pierucci e Mariano, 2010). Perspectiva que remete à sua iniciação na sociologia da religião, dado que a herdou, reflexivamente, de Candido Procopio, que, com os conceitos de catolicismo internalizado em oposição a catolicismo tradicional, na cola de Weber, percebia a mudança religiosa como racionalização da ação religiosa e, por isso, como vetor de mudança cultural em detrimento da tradição e do tradicionalismo religiosos. 
Foi Candido Procopio, com sua pegada weberiana, que o incitou a priorizar o exame da religião como variável independente ou como fator que motiva ou secunda mudanças sociais e culturais, tendo como exemplar emblemático desse modelo de interpretação sociológica $A$ ética protestante. Já na abertura de artigo ${ }^{4}$ escrito a quatro mãos com Reginaldo Prandi em tributo a Procopio, mentor de ambos, afirmou: "Não é a religião enquanto conservação e permanência que deve interessar à sociologia, mas sim a religião em mudança, a religião como possibilidade de ruptura e inovação, a mudança religiosa e, portanto, a mudança cultural" (Pierucci e Prandi, 1996, p. 9). Em 2010, por decisão dele, reproduzimos ipisis litteris esse mantra weberiano e procopiano num artigo não por acaso intitulado "Sociologia da religião, uma sociologia da mudança" para a coletânea de sociologia da Anpocs (Pierucci e Mariano, 2010).

\section{Considerações finais}

Em 1998, Flávio concluiu Secularização segundo Max Weber propondo "não abrir mão da secularização. Nem teórica, nem prática, nem terminológica, nem existencialmente" (Pierucci, 1998, p. 67). Tal declaração, definitivamente, mostra que ele não pode ser definido como um daqueles "especialistas sem coração" descritos por Max Weber. Isto é, apesar de se qualificar como sociólogo materialista da religião, como ele também denominava Weber e sua abordagem sociológica da religião, não lhe faltavam paixão e determinação na defesa de sua perspectiva teórica e de suas preferências políticas.

Dez anos depois, voltou a debater a teoria da secularização num pequeno artigo intitulado "De olho na modernidade religiosa”, à guisa de apresentação do dossiê que organizou sobre sociologia da religião para a Tempo Social: Revista de Sociologia da USP (Pierucci, 2008). Dessa vez, criticou a perspectiva teórica que, em face de certos casos de desprivatização religiosa ou de inserção religiosa na esfera pública, tenta pôr em xeque a força e a validade conceitual da secularização como secularização da normatividade jurídico-política. Em reação, retrucou: "Numa sociedade moderna, a religião quando volta à política, seja de que maneira for, mostra ter o fôlego mais curto do que à primeira vista poderá parecer aos eternos descontentes com a autonomização das esferas de valor e a separação de competências. É o tipo de envolvimento que passa" (Idem, p. 11).

No mesmo texto, concedeu-se ainda um arroubo duplamente militante, tanto teórico quanto político, salientando sua perspectiva teórica sobre a secularização, de um lado, e a defesa de valores seculares e da democracia, de outro. A citação a seguir revela bem suas convicções científicas e ideológicas:

Em matéria de modernidade secular, se eu puder escolher, fico com a "secularização do Estado". Politicamente convencido de que pessoas livres (re) querem Estados laicos, bato-me já há algum tempo (desde 1998 pelo menos) pelo seguinte desideratum: oxalá os cientistas sociais e historiadores passássemos pouco a pouco a incorporar, majoritária e rotineiramente, a ideia de secularização do Estado como um componente crucial, se não o mais crucial de todos, da conceituação histórico-social de uma secularização da qual não pode abrir mão toda modernidade que se preze. Toda vez que falo propositivamente em secularização, refiro-me com ênfase à secularização do Estado com seu ordenamento jurídico, e menos à secularização da vida, que essa pode mesmo refluir, mas a do Estado, não. A do Estado, se for para mudar nalgum aspecto, deve ser somente para afiar cada vez mais a nitidez do seu gume. Isso para mim é cláusula pétrea. Pois então. Em vez de ficarmos a nos agastar girando em falso em torno de uma controvérsia insolúvel a respeito da extensão maior ou menor da secularização entendida como secularização da vida das pessoas, ou mesmo, vá lá, da secularização cultural, seja lá o que isso queira dizer, creio que só teremos a ganhar, tanto no plano teórico quanto no prático, se voltarmos a pensar que a secularização que importa em primeiro lugar a secularização que nos concerne imediatamente, seja enquanto estudiosos, seja principalmente enquanto cidadãos-sujeitos-de-direitos empenhados em preservar e ampliar as liberdades civis e políticas de cada um e de todos "sob o domínio da lei" num "Estado democrático de direito", interessados praticamente, portanto, e não só teoricamente, na observância universalizada de leis revisáveis porque não mais divinamente reveladas -, a seculariza- 
ção que importa antes de tudo, repito, é a secularização do Estado como ordem jurídica (Idem, p. 12).

Depois de ter alertado as esquerdas para as "ciladas da diferença”, nesse texto ele parece novamente procurar alertar os cientistas sociais da religião sobre as eventuais armadilhas do excesso de "boa vontade cultural" com as (ou de pura ingenuidade em relação a) instituições religiosas dotadas de poderes políticos, midiáticos e econômicos e de inclinaçōes teocráticas em detrimento da laicidade do Estado, da secularidade da normatividade jurídica, dos direitos civis, humanos e socioculturais de minorias religiosas, étnicas e sexuais. Por certo, ele não fez tal alerta porque considerasse provável qualquer reversão séria da secularidade do Estado nos países ocidentais e no Brasil. Longe disso. Estava, uma vez mais, demarcando seu terreno, repisando e reforçando seu recado para os colegas de especialização, tentando, em suma, fazer avançar o debate acadêmico sobre a secularização num rumo teórico que lhe parecia mais perspicaz.

Debate cujo teor também é, inextricavelmente, político. Por isso mesmo e por honestidade intelectual, Flávio fazia questão de publicizar sua posição, tanto no ofício de sociólogo quanto no papel de cidadão brasileiro com visibilidade pública, a favor da democracia, das liberdades modernas, da laicidade do Estado e da secularidade da esfera jurídica. Assim, ele nos deixa uma obra inspiradora, recados teóricos e políticos e muitas saudades. Que ninguém é de ferro, como ele dizia.

\section{Notas}

1 Sua autodefinição completa no Lattes é: "especialista em Sociologia da Religião e teoria sociológica alemã, com experiência em Sociologia Urbana e Sociologia Política com foco em comportamento eleitoral".

2 O artigo veio a público primeiramente como conferência ministrada no VIII Congresso Brasileiro de Sociologia, da SBS, em 1997, Brasília.

3 Aula ministrada no concurso para professor titular em Sociologia da Religião da FFLCH-USP, em 26 de abril de 2006.

4 "Assim como não era no princípio: Religião e ruptura na obra de Candido Procopio Ferreira de Camargo", publicado na Novos Estudos, n. 17, em 1987, após o falecimento de Procopio, e em $A$ realidade social das religióes no Brasil: religião, sociedade e política, coletânea escrita com Reginaldo Prandi, lançada pela Editora Hucitec em 1996.

\section{BIBLIOGRAFIA}

BERGER, Peter. (2001), "A dessecularização do mundo: uma visão global”. Religião \& Sociedade, 21 (1): 9-23.

BOURDIEU, Pierre. (1990), "Sociólogos da crença e crenças de sociólogos". In: , Coisas ditas, São Paulo, Brasiliense, pp. 108-113.

CAMARGO, Candido Procopio F. de et al. (1973), Católicos, protestantes, espiritas. Petrópolis, Vozes. HERVIEU-LÉGER, Danièle. (2008), O peregrino e o convertido: a religião em movimento. Petrópolis, Vozes.

MARIANO, Ricardo \& PIERUCCI, Antônio Flávio. (1992), "O envolvimento dos pentecostais na eleição de Collor". Novos Estudos Cebrap, 34: 92-100.

PIERUCCI, Antônio Flávio. (1978), Igreja: contradiçôes e acomodação. Ideologia do clero católico sobre o comportamento reprodutivo. São Paulo, Brasiliense-Cebrap.

(1985), Democracia, igreja e voto. São Paulo, tese de doutorado em Sociologia, Faculdade de Filosofia, Letras e Ciências Humanas da USP (mimeo.).

. (1986), "O povo visto do altar: democracia ou demofilia?". Novos Estudos Cebrap, São Paulo, 16: 66-80.

(1987), "As bases da nova direita". Novos Estudos Cebrap, São Paulo, 19: 26-45.

(1989), "Representantes de Deus em Brasília: a bancada evangélica na Constituinte”, in Anpocs, Ciências Sociais Hoje, 1989, São Paulo, Vértice/Editora Revista dos Tribunais/ Anpocs, pp. 104-132.

(1997a), "Interesses religiosos dos sociólogos da religião", in Ari Pedro Oro e Carlos Alberto Steil (orgs.), Globalização e religiāo, Petrópolis, Vozes, pp. 249-262.

(1997b), "Reencantamento e desse- 
cularização: a propósito do auto-engano em sociologia da religião". Novos Estudos Cebrap, 49: 99-119. . (1998), "Secularização em Max Weber: da contemporânea serventia de voltarmos a acessar aquele velho sentido". Revista Brasileira de Ciências Sociais, 13 (37): 43-73.

. (1999a), Ciladas da diferença. $1^{\mathrm{a}}$ edição. São Paulo, Editora 34.

. (1999b), "Sociologia da religião: área impuramente acadêmica", in Sergio Miceli (org.), O que ler na ciência social brasileira (1970-1995). Vol. II: Sociologia. São Paulo, Sumaré/Anpocs, pp. 237-287. . (2001), A magia. São Paulo, Publifolha. . (2003), O desencantamento do mundo: todos os passos do conceito em Max Weber. São Paulo, Editora 34. (2004), “Bye bye, Brasil’: O declínio das religiões tradicionais no Censo 2000”. Estudos Avançados, 18 (52): 17-28. . (2006a), "Memorial para concurso de professor titular de Sociologia da USP”. São Paulo, FFLCH-USP (mimeo.). . (2006B), "A religião como solvente uma aula”. Novos Estudos Cebrap, São Paulo, 75: 111-127.

. (2008), "De olho na modernidade religiosa”. Tempo Social: Revista de Sociologia da USP, 20 (2): 9-16.

PIERUCCI, Antônio Flávio \& MARIANO, Ricardo. (2010), "Sociologia da religião, uma sociologia da mudança”, in Heloísa Helena T. de Souza Martins (org.), Horizontes das Ciências Sociais no Brasil, São Paulo, Anpocs.

PIERUCCI, Antônio Flávio \& PRANDI, Reginaldo. (1987), "Assim como não era no princípio: religião e ruptura na obra de Procopio Camargo". Novos Estudos Cebrap, 17: 29-35. . (1996), A realidade social das religióes no Brasil. São Paulo, Hucitec.

TAYLOR, Charles. (2010), A era secular. São Leopoldo, Unisinos. 


\section{ANTÔNIO FLÁVIO PIERUCCI: SOCIÓLOGO MATERIALISTA DA RELIGIÃO}

\section{Ricardo Mariano}

Palavras-chave: Antônio Flávio Pierucci; Sociologia da religião; Max Weber; Secularização; Desencantamento do mundo.

$\mathrm{O}$ artigo constitui uma homenagem a Antônio Flávio Pierucci e ao trabalho sociológico que nos legou. Narra sua trajetória na carreira universitária, suas escolhas intelectuais, seus embates acadêmicos e, sobretudo, apresenta parte de sua obra, enfocando, de forma sucinta, sua sociologia da religião de corte weberiano.

\section{ANTONIO FLAVIO PIERUCCI: A MATERIALIST SOCIOLOGIST OF RELIGION}

\section{Ricardo Mariano}

Keywords: Antonio Flavio Pierucci; Sociology of religion; Max Weber. Secularization; Disenchantment of the world.

The article is a tribute to Antonio Flavio Pierucci and the sociological work he has left us. It recounts his trajectory in the university, his intellectual choices, and the intellectual disputes in which he was involved. The main focus, however, is the presentation of Pierucci's works, focusing succinctly his sociology of religion, influenced by Max Weber.

\section{ANTÔNIO FLÁVIO PIERUCCI: SOCIÓLOGUE MATÉRIALISTE DE LA RELIGION}

\section{Ricardo Mariano}

Mots-clés: Antônio Flávio Pierucci: Sociologie de la religion; Max Weber; Sécularisation; Désenchantement du monde.

L'article est un hommage à Antônio Flávio Pierucci et au travail sociologique qu'il nous a légué. Il retrace son parcours universitaire, ses choix intellectuels, ses débats académiques et présente une partie de son œuvre en abordant, de façon succincte, sa sociologie de la religion selon la pensée wébérienne. 